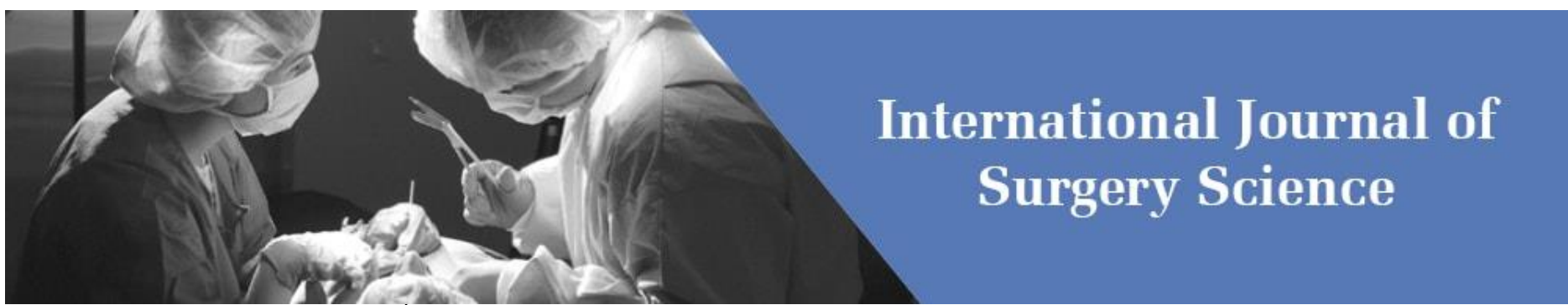

E-ISSN: 2616-3470

P-ISSN: 2616-3462

(c) Surgery Science

www.surgeryscience.com

$2019 ; 3(3): 330-335$

Received: 04-06-2019

Accepted: 30-06-2019

Dr. Gaddala Penchalaiah

Assistant Professor, Department of General Surgery, Guntur Medical

College \& General Hospital,

Guntur, Andhra Pradesh, India

Dr. Lanka Vamsidhar

Assistant Professor, Department of General Surgery, Guntur Medical College \& General Hospital,

Guntur, Andhra Pradesh, India

Correspondence

Dr. Lanka Vamsidha

Assistant Professor, Department of

General Surgery, Guntur Medical

College \& General Hospital,

Guntur, Andhra Pradesh, India

\section{A prospective study on clinical study and laparotomy findings in blunt injury abdomen and its management}

\author{
Dr. Gaddala Penchalaiah and Dr. Lanka Vamsidhar
}

DOI: https://doi.org/10.33545/surgery.2019.v3.i3f.190

\section{Abstract}

Background: Motor vehicle accidents account for most of the cases of blunt injury abdomen. Blunt injury abdomen is most commonly caused by road traffic accidents. The rapid increase in number of motor vehicles and its aftermath has caused rapid increase in number of victims of blunt abdominal trauma. Motor vehicle accidents account for $75 \%-80 \%$ of blunt abdominal trauma.

Aim: The aim of the study is to evaluate the incidence of blunt injury abdomen, clinical presentation, findings of laprotomy, study the mode of treatment, mortality, and morbidity.

Methodology: This is a prospective study of 50 cases of blunt injury abdomen conducted in Government General Hospital, Guntur. From November 2015 to October 2017.

Results: Males (92\%) outnumbered females (8\%). The most common age group affected is 21-30 yrs, which forms the young and reproductive group. Road traffic accidents form the most common mode of injury accounting up to $86 \%$. Majority of our study population $(84 \%)$ presented with pain abdomen followed by features of peritonitis $(56 \%)$. The latent period in our study was less than $12 \mathrm{hrs}$ in $64 \%$ of patients. Haemoglobin and hematocrit values become handy in blunt injury abdomen patients, X-ray erect abdomen and chest X-ray forms important investigation tools. Ultra sonography (FAST) has picked up solid organ injury in $68 \%$ of cases. Four quadrant aspiration is a simple and non specific diagnostic tool. CECT abdomen was performed in $70 \%$ of study population and had pivotal role in deciding operative versus conservative management in hemodynamically stable cases. The most common injured organ is spleen followed by liver and small intestine in descending order. For splenic injury most common surgery performed was splenectomy in 11 patients followed by 6 patients. Liver injury was managed with hepatorraphy in $8 \%$ cases followed gel foam application in $2 \%$ case. Next most common organ was small intestine, jejunum involved in 5 cases followed by ileum in 4 cases. Isolated mesenteric tear was seen in 2 cases, mesentery injury associated with other organs was seen 6 cases. Jejunal and ileum has perforations and closure of perforation was done 5 cases, resection anastomosis was done in 2 cases. Mesenteric injury is most commonly associated with splenic injury it was seen in $6 \%$ of cases. Mesenteric rent closure is the most treatment offered $12 \%$ of cases. Large intestine injury was seen in $8 \%$ cases colostomy was the treatment in half of the cases. Duodenal injury is associated with pancreatic injury in single case. Pancreatic injury was seen in 5 cases. 3 patients were died with pancreatic injury making pancreatic injury management as most challenging. Laparotomy drainage procedure treatment offered in 4 cases of pancreatic injury.

Conclusion: Blunt injury abdomen with solid organ injury forms considerable load of patients in our society. Road traffic accidents form the most common mode of injury. So efforts should be made to bring road traffic regulations into strict action and traffic norms regulated. CECT forms the core investigation of choice in dealing with blunt injury abdomen patients, and becomes more important in deciding operative versus conservative management. Early diagnosis and repeated clinical examination and use of appropriate investigation form the key in managing blunt injury abdomen patients.

Keywords: Blunt Injurt, road traffic accidents, laprotomy, ultrasonography

\section{Introduction}

Blunt injury abdomen is most commonly caused by Road traffic accidents ${ }^{[1]}$. The rapid increase in number of motor vehicles and its aftermath has caused rapid increase in number of victims of blunt abdominal trauma. Motor vehicle accidents account for $75-80 \%$ of blunt abdominal trauma ${ }^{[2]}$. Blunt abdominal injury is also a result of fall from height, assault with objects, industrial mishaps, sports injuries, bomb blast and fall from riding bicycle ${ }^{[2]}$. Blunt abdominal trauma is usually not obvious. Hence often missed, unless repeatedly looked for. Due to the delay in diagnosis and inadequate treatment of the abdominal injuries, most of the cases are fatal. 
The knowledge in the management of blunt abdominal has progressively increasing. Inspite of the best techniques and advances in diagnostic and supportive care, the mortality and morbidity remains at large. The reason for this could be due to the interval between the trauma and hospitalisation, inadequate and lack of appropriate surgical treatment, delay in diagnosis, post operative complications and associated trauma especially to head and thorax.

In view of increasing number of vehicles and consequently road traffic accidents this study has been chosen to find the cases of blunt injury abdomen presenting at govt. general hospital Guntur attached to Guntur medical college.

\section{Aim of the present study is to}

1. know the incidence and the Etiology, mode of presentation, and nature of injury to different intra-abdominal organs

2. To assess the importance of the various investigations.

3. To study different findings in laparotomy \& study the mode of treatment offered.

4. To study mortality morbidity assocaiated with blunt trauma abdomen.

\section{Materials and Methods}

\section{Source of data and period of study}

The present study "a clinical study on laprotomy findings in blunt injury abdomen" comprises of patients admitted to and operated in various surgical units in the Department of Surgery at Government General Hospital, Guntur, attached to Guntur medical college Guntur, from December 2015 to November 2017.

\section{Collection of data, sample size and mode of selection}

50 patients with blunt abdominal injuries admitted in surgical wards included in the study. Patients were methodically enquired according to the proforma approved by the guide. A detailed history as to the mode of injury, thorough clinical examination and necessary investigations like routine investigations, special investigations including ultrasound and CT scan were done.

\section{Inclusion Criteria}

All patients with blunt abdominal injury for whom laparotomy was done with intra abdominal injuries were included in the study.

\section{Exclusion criteria}

Those patients admitted with blunt injury abdomen but managed conservatively the. Patients who died before confirmation of definitive diagnosis were also excluded from this study.

\section{Method}

The management was individualized and each case was assessed on its own. In patients where laparotomy was performed after resuscitation, the details regarding the viscera injured and nature of surgery performed were recorded.

Each case was carefully followed up to evaluate the progress of patient and to note the development of complications, if any and its management. The details of all cases are summarized in the master chart and results of the study have been analyzed in detail.

\section{Results}

The present study carried out From December 2015 to
November 2017, 50 number of cases were studied which belong to surgical units in Government General Hospital, Guntur.

Table 1: Sex incidence

\begin{tabular}{|c|c|c|}
\hline Gender & No of patients & Percentage \\
\hline Male & 46 & $92 \%$ \\
\hline Female & 4 & $8 \%$ \\
\hline
\end{tabular}

Table 2: Age group

\begin{tabular}{|c|c|c|}
\hline Age group & No of patients & Percentage \\
\hline $11-20$ & 9 & $18 \%$ \\
\hline $21-30$ & 21 & $42 \%$ \\
\hline $31-40$ & 11 & $22 \%$ \\
\hline $41-50$ & 6 & $12 \%$ \\
\hline $51-60$ & 3 & $6 \%$ \\
\hline
\end{tabular}

In this study, majority of patients belong to 21-30 years of age accounting to 42 percent followed by $31-40$ years of age.

Table 3: Showed mode of Injury

\begin{tabular}{|c|c|c|}
\hline Cause & No of cases & Percentage \\
\hline Road traffic accidents & 43 & $86 \%$ \\
\hline Fall From Height & 4 & $8 \%$ \\
\hline Agricultural form injury & 3 & $6 \%$ \\
\hline
\end{tabular}

In the present study, in 86 percent of cases mode of injury is RTA followed by fall from height accounting 8 percent. Least was agricultural work based injury.

Table 4: Clinical Presentation

\begin{tabular}{|c|c|c|}
\hline Presentation & NO of cases & percentage \\
\hline Abdominal pain & 42 & $84 \%$ \\
\hline Abdominal distension & 12 & $24 \%$ \\
\hline Abdominal guarding and rigidity & 28 & $56 \%$ \\
\hline shock & 4 & $8 \%$ \\
\hline
\end{tabular}

In the present study, 84 percent of the patients presented with abdominal pain followed by abdominal guarding and rigidity. Only 8 percent of patients presented with shock.

Table 5: Latent period

\begin{tabular}{|c|c|c|}
\hline Hours/days & No of patients & percentage \\
\hline $0-12 \mathrm{hrs}$ & 32 & $64 \%$ \\
\hline $12-24 \mathrm{hrs}$ & 14 & $28 \%$ \\
\hline 1-4days & 4 & $8 \%$ \\
\hline
\end{tabular}

64 percent of people present with first $12 \mathrm{hr}$ of injury. 8 percent people late period of upto 4 days.

Table 6: Associated injuries

\begin{tabular}{|c|c|c|}
\hline Associated injury & No of cases & percentage \\
\hline Head & 6 & $12 \%$ \\
\hline Thorax & 16 & $32 \%$ \\
\hline Extremities & 10 & $20 \%$ \\
\hline Pelvis & 3 & $6 \%$ \\
\hline Soft tissue injury & 2 & $2 \%$ \\
\hline No association & 13 & $26 \%$ \\
\hline
\end{tabular}

Associate injury along with abdominal injury was present in 37 cases. The common extra abdominal injury was thoracic in the form of fractured ribs and Hemothorax followed by extremities fracture, head injury, pelvis and soft tissue injury. 


\section{Investigations}

Tables 7: Levels of haemoglobin

\begin{tabular}{|c|c|c|}
\hline Hb & No of cases & percentage \\
\hline More than $10 \mathrm{gm}$ & 19 & $38 \%$ \\
\hline $8-10$ & 18 & $36 \%$ \\
\hline Less than 8 & 13 & $26 \%$ \\
\hline
\end{tabular}

In the present study, Haemoglobin was above $10 \mathrm{~g}$ min 38 percent of patients and was below $8 \mathrm{gm}$ in 26 percent of cases.

Table 8: Hematocrit value

\begin{tabular}{|c|c|c|}
\hline Hematocrit & No of patients & percentage \\
\hline Below 30 & 20 & $40 \%$ \\
\hline $30-45$ & 9 & $18 \%$ \\
\hline Above 45 & 16 & $32 \%$ \\
\hline Not done & 5 & $10 \%$ \\
\hline
\end{tabular}

Hematocrit was done in 45 patients and was not done in 5 cases.

Table 9: Urine microscopy

\begin{tabular}{|c|c|c|}
\hline Urine microscopy & No of cases & Percentage \\
\hline normal & 40 & $80 \%$ \\
\hline Macro Hematuria & 05 & $10 \%$ \\
\hline Microhematuria & 05 & $10 \%$ \\
\hline
\end{tabular}

Urine microscopy showed RBCs in 20 percent of cases and normal in 80percent of cases.

Table 10: X-ray Erect Abdomen

\begin{tabular}{|c|c|c|}
\hline Xray Erect Abdomen & No of cases & percentage \\
\hline Ground glass appearance & 23 & 46 \\
\hline Gas under diaphragm & 16 & 32 \\
\hline No abnormality & 7 & 14 \\
\hline Not done & 4 & 8 \\
\hline
\end{tabular}

Plain Xray Erect Abdomen was done in 46 cases and was not done in 4 cases as they were hemodynamically unstable. 20 percent of $\mathrm{X}$ ray Erect Abdomen was normal in our series.

Table 11: Four Quadrant Aspiration

\begin{tabular}{|c|c|c|}
\hline FQA & No of cases & percentage \\
\hline positive & 30 & $60 \%$ \\
\hline Negative & 14 & $28 \%$ \\
\hline Not done & 6 & $12 \%$ \\
\hline
\end{tabular}

In the present study 30 cases showed positive

\section{Ultrasonography of abdomen}

Table 12: Organ injury in USG abdomen

\begin{tabular}{|c|c|c|}
\hline Organ & No cases & Percentage \\
\hline Spleen & 19 & $38 \%$ \\
\hline Liver & 12 & $24 \%$ \\
\hline Kidney & 1 & $2 \%$ \\
\hline Pancreas & 2 & $4 \%$ \\
\hline Hollow viscus & 0 & 0 \\
\hline Mesentery & 0 & 0 \\
\hline
\end{tabular}

USG was done in all 50 cases. Major injuries observed in spleen $38 \%$ which is followed by liver $24 \%$.
Table 13: CECT abdomen

\begin{tabular}{|c|c|}
\hline Organ injured & No of cases \\
\hline Spleen & 12 \\
\hline Liver & 10 \\
\hline Hollow viscus & 9 \\
\hline Pancreas & 3 \\
\hline Kidney & 1 \\
\hline
\end{tabular}

CECT was done in 35 cases. It observed spleen injuries occurred in more number of patients (12) which is followed by liver (10). Those patients who did not underwent CECT either they were taken for laparotomy or hemodynamically unstable.

\section{Isolated organ wise injury}

Table 14: Organ wise injury

\begin{tabular}{|c|c|c|}
\hline Organ & No of cases & Percentage \\
\hline spleen & 14 & $28 \%$ \\
\hline liver & 9 & $18 \%$ \\
\hline jejunum & 3 & $6 \%$ \\
\hline ileum & 3 & $6 \%$ \\
\hline Pancreas & 3 & $6 \%$ \\
\hline colon & 2 & $4 \%$ \\
\hline Mesentery & 2 & $4 \%$ \\
\hline caecum & 1 & $2 \%$ \\
\hline rectum & 1 & $2 \%$ \\
\hline kidney & 1 & $2 \%$ \\
\hline
\end{tabular}

In our study, spleen was the most commonly injured organ.

\section{Multiple organs involved}

Table 15: Organ wise injury

\begin{tabular}{|c|c|}
\hline Organs injured & No of cases \\
\hline Spleen and mesentery & 3 \\
\hline Jejunum and mesentery & 2 \\
\hline Jejunum and pancreas & 1 \\
\hline Liver and mesentery & 1 \\
\hline Liver and spleen & 1 \\
\hline Duodenum and pancreas & 1 \\
\hline Liver, ileum and colon & 1 \\
\hline superior mesenteric artery with mesentery & 1 \\
\hline
\end{tabular}

\section{Types of surgery}

The below data shows various operative procedures carried out during exploratory laparotomy.

Table 16: Type of surgery

\begin{tabular}{|c|c|c|}
\hline Procedure & $\begin{array}{c}\text { No of } \\
\text { patients }\end{array}$ & percentage \\
\hline Splenectomy & 11 & $22 \%$ \\
\hline hepatorraphy & 8 & $16 \%$ \\
\hline Closure of perforation & 7 & $14 \%$ \\
\hline Splenorrhaphy & 4 & $8 \%$ \\
\hline Resection anastomosis & 4 & $8 \%$ \\
\hline drainage procedure & 3 & $6 \%$ \\
\hline Splenorrhaphy and mesenteric closure & 3 & $6 \%$ \\
\hline Mesenteric rent closure & 2 & $4 \%$ \\
\hline colostomy & 2 & $4 \%$ \\
\hline Resection anastomosis and mesenteric closure & 1 & $2 \%$ \\
\hline Hepatorrhaphy and splenorrhaphy & 1 & $2 \%$ \\
\hline Resection anastomosis and pancreatic tube & 1 & $2 \%$ \\
\hline $\begin{array}{c}\text { Hepatorraphy and closure of perforation and } \\
\text { resection anastomosis }\end{array}$ & 1 & $2 \%$ \\
\hline \multicolumn{2}{|c|}{} \\
\hline
\end{tabular}


Table 17: Complications of Post-operative

\begin{tabular}{|c|c|}
\hline Post op complications & No of patients \\
\hline Wound infection & 3 \\
\hline Respiratory complications & 5 \\
\hline Wound dehiscence & 1 \\
\hline Intra abdominal abscess & 1 \\
\hline
\end{tabular}

Table 18: Duration of stay

\begin{tabular}{|c|c|c|}
\hline No of days & No of patients & Percentage \\
\hline $1-10$ & 18 & $36 \%$ \\
\hline $11-20$ & 22 & $44 \%$ \\
\hline $21-30$ & 5 & $10 \%$ \\
\hline $31-40$ & 2 & $4 \%$ \\
\hline $41-50$ & 2 & $4 \%$ \\
\hline More than 50 & 1 & $2 \%$ \\
\hline
\end{tabular}

The range varied from 10-54 days. The mean range of stay is 16days.

\section{Mortality}

Total three patients died in this study. Two cases have pancreatic injury. One case have duodenal transection injury along with grade iv pancreatic injury. Therefore the mortality rate was 6 percent.

\section{Discussion \\ Sex incidence}

From the below table it is clear that males are more common victims of blunt trauma abdomen when compared to Davis et al ${ }^{3}$ study and Vikram Yogesh et al. ${ }^{[4]}$ study. The incidence is slightly more in male as males are more involved in RTA.

Table 19: Gender comparision

\begin{tabular}{|c|c|c|c|}
\hline Gender & Our study & Davis et al. $^{\left[{ }^{3]}\right.}$. & Vikram Yoghs et al. \\
\hline Males & $92 \%$ & $70 \%$ & $75 \%$ \\
\hline Females & $8 \%$ & $30 \%$ & $25 \%$ \\
\hline
\end{tabular}

\section{Age incidence}

Table 20: Age group

\begin{tabular}{|c|c|c|c|}
\hline $\begin{array}{c}\text { Age } \\
\text { group }\end{array}$ & $\begin{array}{c}\text { Percentage in our } \\
\text { study }\end{array}$ & $\begin{array}{c}\text { Davis } \text { et al. } \\
{\left[{ }_{3} \text {. }\right.}\end{array}$ & $\begin{array}{c}\text { Yogesh } \text { et al. } \\
{[4]}\end{array}$ \\
\hline $11-20$ & $18 \%$ & $19 \%$ & $4 \%$ \\
\hline $21-30$ & $42 \%$ & $24 \%$ & $45 \%$ \\
\hline $31-40$ & $22 \%$ & $15 \%$ & $30 \%$ \\
\hline $41-50$ & $12 \%$ & $13 \%$ & $10 \%$ \\
\hline $51-60$ & $6 \%$ & $6 \%$ & $9 \%$ \\
\hline
\end{tabular}

Age group: in our study majority of the population belonged to 21-30yrs of age followed by 31-40yrs of age as young people are involve in RTA which is compare to Davis et al. and Vignes et al.

Table 21: Mode of injury

\begin{tabular}{|c|c|c|c|}
\hline Cause & $\begin{array}{c}\text { Percentage } \\
\text { in our study }\end{array}$ & $\begin{array}{c}\text { Davis } \text { et al. } \\
{\left[{ }^{[3]} \text {. }\right.}\end{array}$ & $\begin{array}{c}\text { Vikram Yogesh } \\
\text { et al. }{ }^{[4]} \text {. }\end{array}$ \\
\hline Road traffic accidents & $86 \%$ & $70 \%$ & $57 \%$ \\
\hline Fall From Height & $8 \%$ & $6 \%$ & $15 \%$ \\
\hline Agricultural form injury & $6 \%$ & & \\
\hline
\end{tabular}

From the above table it clearly states that RTA is the most common mode of injury because of increased number of vehicles recently. The young people also give priority to speed rather than safety.

\section{Clinical presentation}

In our study abdominal pain was the most common presenting complaint accounting $84 \%$. Peritonitis was the next most common presentation in $56 \%$ of patients. The signs and symptoms are misleading in case of blunt trauma abdomen and are masked by concomitant head injury, chest injury and alcoholic consumption. Retro peritoneal organ injury was missed in USG abdomen. In Davis et al. ${ }^{[3]}$ study $43 \%$ had no specific complaints. so this emphasizes the importance of careful and continuing observation and repeated clinical examination of individual with

\section{Latent period}

Latent period is the interval between the time of injury to presentation to our hospital. In our study $64 \%$ of patients presented between 1-12 hr after injury. 24\% presented $12-24 \mathrm{hrs}$ after surgery. This time lag is due to lack of facility for transport. Patient tolerance of pain in rural areas, negligence of attenders and lack of proper health care at peripheral centres.

Table 22: Associated injuries

\begin{tabular}{|c|c|c|c|}
\hline Associated injury & percentage & Davis et al. ${ }^{[3]}$. & Khanna et al. ${ }^{\left[{ }^{[3}\right]}$. \\
\hline Head & $12 \%$ & $9 \%$ & $12 \%$ \\
\hline Thorax & $32 \%$ & $27 \%$ & $24 \%$ \\
\hline Extremities & $20 \%$ & 15 & $27 \%$ \\
\hline Pelvis & $6 \%$ & & \\
\hline Soft tissue injury & $2 \%$ & $12 \%$ & \\
\hline No association & $26 \%$ & & \\
\hline
\end{tabular}

Associated injury was present in 37 cases. The most extra abdominal injury was thoracic accounting for $32 \%$ followed by extremity fracture, head injury, pelvic fracture and soft tissue injury in descending order. There was no association in13 patients. The above table shows comparison to the present study.

\section{Haemoglobin}

Hemoglobin percentage was done in all cases out of which $26 \%$ have $<8 \mathrm{gm} \%$.

\section{Hematocrit}

Hematocrit value was done in 45 patients. It was $<30$ in $40 \%$ of our study population. In 5 cases there was decreasing hematocrit on serial measurement.

\section{Urine microscopy}

Urine microscopy was done in all cases. There was hematuria either macro /micro hematuria in $2 \%$ percent of cases which had renal injury on CT scan.

\section{Plain X ray Erect Abdomen}

Plain X ray Erect abdomen was done in 46 patients. Gas under diaphragm was found in 12 patients. in Davis et al. it was found in 10 percent cases.

Table 23: Four quadrant aspiration

\begin{tabular}{|c|c|c|}
\hline FQA & Percentage in our study & Davis et al. ${ }^{[3]}$. \\
\hline Positive & 60 & $46 \%$ \\
\hline Negative & 28 & $10 \%$ \\
\hline Not done & 12 & $5 \%$ \\
\hline
\end{tabular}

\section{Ultrasound examination}

USG abdomen (Focussed assessment with sonography for trauma) a was done in all cases out of which 42 cases have solid organ injury free fluid in abdomen was found in nearly 45 cases. 
Therefore USG was more reliable in solid organ injury than hollow viscus injury.

Table 24: From above table, splenic injury is the most common finding in USG, Followed by liver injury. relatively less specific in hollow viscus injury.

\begin{tabular}{|c|c|c|c|c|c|}
\hline Organ & $\begin{array}{c}\text { Percentage } \\
\text { in our study }\end{array}$ & Cusheri $^{\text {Davis } \text { et }}$ & $\begin{array}{c}\text { Cox } \text { et } \\
\text { al. }^{[3]} \text {. }\end{array}$ & $\begin{array}{c}\text { Khanna } \text { et } \\
\text { al] }^{[6}\end{array}$ & al. $^{[5]}$. \\
\hline Spleen & $\mathbf{3 8 \%}$ & $\mathbf{2 5 \%}$ & $\mathbf{2 5 \%}$ & $\mathbf{4 6 \%}$ & $\mathbf{2 6 \%}$ \\
\hline Liver & $24 \%$ & $15 \%$ & $16 \%$ & $33 \%$ & $37 \%$ \\
\hline Kidney & $2 \%$ & & & & \\
\hline Pancreas & $4 \%$ & & & & \\
\hline Hollow viscus & 0 & & & & \\
\hline Mesentery & 0 & & & & \\
\hline
\end{tabular}

Imaging is essential in early decision making. focused assessment with sonography in trauma (FAST) examination of pericardial, Perihepatic, Perisplenic and pelvis areas help in early detection of clinically significant abdominal injury.

FAST examination can be performed repeatedly and is excellent adjuvant to physical examination.

\section{CECT abdomen}

CECT was done in 35 cases. SIX patients were presented in shock immediately took for laparotomy after FAST. It can accurately diagnose the grade of solid organ injury. It can also pick up retroperitoneal organ injury like kidney and pancreas. In our study CECT was accurate for 12 cases of spleen, 10 cases of liver, detected 3 out of 5 cases of pancreatic injury. It also help to detect hollow viscus injury non specifically up to $18 \%$ of the cases. Most consist finding in our study is $98 \%$ it can detect Hemoperitoneum.

Table 25: Organ injury found in our study compared with other study

\begin{tabular}{|c|c|c|c|c|}
\hline Organ & $\begin{array}{c}\text { Our } \\
\text { study }\end{array}$ & Davis et al. ${ }^{[3]}$ & Cox et al. ${ }^{[6]}$ & Hackamn et al. ${ }^{[7]}$. \\
\hline Spleen & $36 \%$ & $25 \%$ & $46 \%$ & \\
\hline Liver & $24 \%$ & $16 \%$ & $33 \%$ & \\
\hline Kidney & $2 \%$ & & & \\
\hline Bowel injury & $34 \%$ & & & $34 \%$ \\
\hline Pancreas & $20 \%$ & & & \\
\hline
\end{tabular}

Our study was have similar percentage in case of splenic injury, followed by liver injury and bowel injury. Bowel injury has same percent when compared with Hack man et al. study. Splenic injury has relatively similar incidence when compared with Davis et al, Cox et al. studies.

Table 26: Operative procedure

\begin{tabular}{|c|c|c|}
\hline Procedure & Percentage in our study & Vikram Yogesh et al. ${ }^{[4]}$. \\
\hline Splenectomy & 22 & $53 \%$ \\
\hline Hepatorraphy & 16 & $24 \%$ \\
\hline Closure of perforation & 14 & $7 \%$ \\
\hline Splenorrhaphy & 8 & \\
\hline Resection anastomosis & 8 & $12 \%$ \\
\hline drainage procedure & 6 & \\
\hline Splenorrhaphy and mesenteric closure & 6 & \\
\hline Mesenteric rent closure & 4 & \\
\hline Colostomy & 4 & \\
\hline Hepatorraphy and mesentri closure & 2 & \\
\hline Resection anastomosis and mesenteric closure & 2 & \\
\hline Hepatorrhaphy and splenorrhaphy & 2 & \\
\hline Resection anastomosis and pancreatic tube & 2 & \\
\hline Hepator "'."raphy and closure of perforation and resection anastomosis & 2 & \\
\hline
\end{tabular}

Our study has similar rate spleencetomy when compared to other studies. Followed by primary closure with heaptorraphy. In our study most common GIT surgery performed is resection and anastomosis similar to other studies.

Table 27: Multiple organ injury in blunt trauma

\begin{tabular}{|c|c|c|}
\hline Organs injured & $\begin{array}{c}\text { No of cases in } \\
\text { our study }\end{array}$ & $\begin{array}{c}\text { Aziz } \text { et al. } \\
{[8]}\end{array}$ \\
\hline Spleen and mesentery & 3 & \\
\hline Jejunum and mesentery & 2 & \\
\hline Jejunum and pancreas & 1 & 1 \\
\hline Liver and mesentery & 1 & \\
\hline Liver and spleen & 1 & \\
\hline Duodenum and pancreas & 1 & 1 \\
\hline Liver, ileum and colon & 1 & 3 \\
\hline superior mesenteric artery with mesentery & 1 & \\
\hline
\end{tabular}

\section{Conclusion}

Blunt injury abdomen with solid organ injury forms considerable load of patients in our society. Most common age group involved is 21-30 years. Predominantly males are affected in large proportions. Road traffic accidents form the most common mode of injury. So efforts should be made to bring road traffic regulations into strict action and traffic norms regulated. Well established trauma care centres should be established at every Taluk hospitals. Measures for early transport of the patients from the accident site to the trauma centres should be undertaken. Significant number of cases will have associated injuries with blunt injury abdomen like head injury, thoracic injury, extremity fractures. Blunt injury abdomen is usually less obvious. Hence, repeated examinations by multi specialty personnel in a specialized trauma center are required. Erect abdomen $\mathrm{X}$ ray is a useful investigation to identify associated hollow viscus injury. Falling titers in serial hematocrit value indicates ongoing bleeding. With advent of high resolution, ultrasonography (FAST) and FQA investigations are becoming less opted. CECT forms the core investigation of choice in dealing with blunt injury abdomen patients, and becomes more important in deciding operative versus conservative management. Early diagnosis and repeated clinical examination and use of appropriate investigation forms the key in managing blunt injury abdomen patients. Associated extra abdominal injuries like head, thoracic and orthopedic injuries influenced the morbidity and mortality of the patients. 


\section{Acknowledgement}

The authors thankful to Dept. Of Surgery for providing all the facilities to carry out this study.

\section{Conflict of interest}

The authors declare that they have no conflict of interest.

\section{References}

1. Cusheri A, George Hanna A. R: Essential Surgical Practice; Butterworth International $4^{\text {th }}$ Ed, 2013, 263-304.

2. Sabiston's Text book of surgery: 19tt' edition. 2012; 1:455459.

3. Joe Jack Davis, Isidore Cohn, Francis C. Nance; Diagnosis and management of Blunt abdominal trauma. Ann, Surg. 1976; 183(6):672-678.

4. Vikram Yogish, Venkateswaran PS, Rajkamal C. A study of blunt injury abdomen in patients attending the emergency department in a tertiary hospital. Int. Surg J. 2016; 3:153-7.

5. Khanna R, Khanna S, Singh P, Puneet, Khanna AK. Spectrum of blunt abdominal trauma in Varanasi; Quart J. 1999; 35(1/2):25-28.

6. Cox, Everard F. Blunt abdominal trauma: A 5.year Analysis of 870 patients requiring Celiotomy; Ann, Surg. 1984; 1(199)467-474.

7. Hackman DJ, Ali J, Jastaniah SS. Neugebauer H, Wallwnboeck E, Hungerford M. Seventy Cases of Injuries of the Small Intestine Caused by Blunt Abdominal Trauma: A..

8. Aziz A, Bota R, Ahmed M. Frequency and Pattern of IntraAbdominal Injuries in Patients with Blunt Abdominal Trauma. J Trauma Treat. 2014; 3:196. doi:10.4172/21671222.1000196 